\title{
SPATIAL AND INSTITUTIONAL CHARACTERISTICS OF INLAND PORT DEVELOPMENT IN CHINA
}

\author{
Jason MONIOS \\ Yuhong WANG \\ Transport Research Institute, Edinburgh Napier University \\ Merchiston Campus \\ Edinburgh EH10 5DT \\ United Kingdom \\ Email address: j.monios@napier.ac.uk
}

This is the pre-published version of the text. The final published paper can be found at:

Monios, J., Wang, Y. (2013). Spatial and institutional characteristics of inland port development in China. GeoJournal. 78 (5): 897-913.

DOI: $10.1007 / s 10708-013-9473-2$

\begin{abstract}
This paper examines the spatial and institutional characteristics of the emerging trend of inland port development in China. The paper analyses a sample of 18 major inland ports in three geographical clusters, comparing observed issues with similar developments in Europe, the United States and Africa. It highlights the issues of customs clearance and intermodal transport, before an extended discussion on conflicting models of development based on the priorities of inland and port actors.
\end{abstract}

The aim is first to provide a descriptive account of this development, and second to provide tentative explanations for these results by comparing the findings with similar developments in other countries. This task is aided by use of a conceptual framework drawn from the literature, in which port-driven and inland-driven inland ports are contrasted. Thus a supplementary aim of the paper is to develop the conceptual model of directional development in a new geographical context.

Findings reveal the need to align development priorities of central and local governments, as well as clarifying the use of subsidies to a number of different inland ports which may potentially split economies of scale through increased competition for an overlapping hinterland. The paper demonstrates that, while in the past China's seaports had less inland penetration compared to more mature systems, emerging trends suggest some similarities to patterns observed in more integrated networks such as Europe and North America.

Key words inland port; logistics; freight; intermodal transport; rail; policy; planning; port authority; inland terminal; port competition 


\section{Introduction}

It has been ten years since the first inland port emerged in China in 2002. Over the last decade, major Chinese seaports have paid increasing attention to the need to develop inland ports due to the competitive pressures of overlapping hinterlands with neighbouring ports. Inland cities have also evinced significant interest in this concept with the purpose of enhancing the competitiveness of their local economies. Now there are more than 20 significant inland ports in operation in China, with more under construction.

Inland ports can be developed in the hinterland according to different strategies, involving differing motivations, actors, functions and logistics models. They can be close to the port, mid-range or distant. They can be built to ease port congestion or for reasons of hinterland capture and port competition. They can be developed by port authorities, port terminal operators and transport providers such as rail operators or third-party logistics providers (3PLs), or they can be developed by public bodies, whether national, regional or local. They can be designed on a rail-based strategy of generating economies of scale on high-capacity, long-distance links. By contrast, they can be road-based short-distance satellite terminals to ease port congestion or facilitate fast-track customs clearance.

Academic literature over the past decade has begun to develop conceptual models to classify and analyse different strategies of inland port development, with a dominant focus on Europe and the United States (e.g. Rodrigue \& Notteboom 2009; Roso et al. 2009; Bergqvist et al. 2010; Rodrigue et al. 2010; Monios \& Wilmsmeier 2012). While in recent years some literature on Asia, Africa and Latin America has begun to be published, it remains the case that a geographical understanding of the spatial development of freight transport in developing economies has been insufficiently developed ( $\mathrm{Ng} \&$ Cetin 2012; Notteboom \& Rodrigue 2009a). Research is now beginning to emerge on Chinese inland ports (e.g. 
Hanaoka \& Regmi 2011; Beresford et al. 2012; Lu \& Chang 2013); this paper will contribute towards this emerging tradition.

While the hinterland freight geography of North America represents a landbridge and Europe is based on coastal gateways and inland load centres, the East Asian hinterland model has been categorised as coastal concentration with low inland coverage (Lee et al. 2008). European and North American seaports are generally conceptualised as increasingly integrated with their hinterlands (Notteboom \& Rodrigue 2005), however, Rimmer \& Comtois (2009) criticised this approach because of what in their view is an inappropriate focus on the hinterland dimension of port development. In any case, the lack of inland penetration of Chinese ports would suggest that hinterland integration models do not apply there. However, this spatial pattern has been altered by the establishment of several inland ports in the Chinese hinterland over the last decade. Questions are thus raised regarding the extent to which issues experienced in Europe and North America have been or will be repeated in China.

This paper will address these issues through a spatial and institutional analysis, first providing a descriptive account of inland port development in China, and second, proposing tentative explanations for these results by comparing the findings with similar developments in other countries. Previous research has shown that spatial and institutional aspects intersect in the successful development of hinterland transport, and attempts have been made to conceptualise this intersection by contrasting port-driven and inland-driven inland ports (Monios \& Wilmsmeier 2012), seeking a more interdisciplinary transport geography (Hall 2010). This approach will be utilised in this paper to analyse the sample from a conceptual perspective, enabling comparisons with other continents in order to establish whether the spatial and institutional geography of China's intermodal transport development is following 
patterns observed in more mature systems. Thus a supplementary aim of the paper is to develop the conceptual model of directional development in a new geographical context.

The paper begins with a literature review to develop the conceptual background to the paper, followed by a description of the methodology. Results of the sample analysis are then presented in three parts: geographical analysis of inland port locations, the role of customs reform and the development of intermodal transport. This section is followed by a comparison with developments in other continents. The conceptual model derived from the literature is then applied, attempting to explain trends in China via a spatial and institutional discussion. Finally, different strategies of inland port development are compared and contrasted, including a discussion of these two models from a global perspective.

\section{Theoretical background to the paper}

Major issues in the literature relating to intermodal transport and hinterland access include the increasing vertical integration in the supply chain (Heaver et al. 2000; Heaver et al. 2001; Frémont \& Soppé 2007; Hayuth 2007; Olivier \& Slack 2006; Notteboom 2008), the emerging focus on the terminal rather than the port (Konings 1996; Slack \& Wang 2002; Slack 2007), and the shift in focus towards the land-side activities of the port (Bichou \& Gray 2004; Parola \& Sciomachen 2009). The result of this trend is the present focus on inland terminals and inland ports.

Hierarchies in the transport chain are being altered as a result of the port's transformation from a monopoly position to a node within the logistics chain (Robinson 2002). Ports therefore need to be active in extending or even maintaining their hinterlands. The literature has shown that inland terminals can be used in a competitive manner, particularly as the inland leg contributes the majority of the door-to-door cost (Van Klink \& van den Berg 1998; McCalla 1999; Notteboom \& Rodrigue 2005). However, research on intermodal transport 
does not always clarify which component of the total inland logistics cost is being reduced through the adoption of an inland port strategy. In some cases it is the transport cost, while in others it is customs charges and related cash flow issues or the removal of unnecessary delays from the system. In other cases, it is the use of key nodes to rationalise supply chain functions such as inventory management or value-added activities.

Inland freight handling nodes in the hinterland have acquired various names over the years, such as Inland Clearance Depot (ICD), a term that focuses on the ability to provide customs clearance at an inland location. Similarly, the term "dry port" has often been used interchangeably with ICD (Beresford \& Dubey 1991; Garnwa et al. 2009), and more recently to describe a kind of integrated logistics site (Roso et al. 2009), thus sharing similarities with freight villages or logistics parks (see also GVZ in Germany, ZAL in Spain, interporti in Italy). Discussions can also focus on the operational link between the port and the inland site, such as a high capacity link (rail or barge) and a high level of operational integration in the management of that link (Roso et al. 2009; Monios 2011; Veenstra et al. 2012). Other terms include inland terminal, intermodal terminal and inland port. Rodrigue et al. (2010) related this multiplicity of terms to the variety of geographical settings, functions, regulatory settings and the related range of relevant actors, and preferred the term "inland port" as an overall term representing inland nodes of various types and sizes.

The distinction drawn by Rodrigue et al. (2010) between satellite terminals, transmodal centres and load centres is similar to the close, mid-range and distant dry port model presented by Roso et al. (2009) and the later sea port-based, city-based and border-based model proposed by Beresford et al. (2012). This kind of functional approach, based on the usage of each node, has more utility than overall terms such as "dry port" or "inland port". It allows a research agenda to be developed along the lines of the purpose and usage of these nodes in the transport chains that they shape. 
Rodrigue et al. (2010) drew a distinction between the transport and supply chain functions of a site. This paper will develop that research agenda through a discussion of the motivations for shippers to use an inland site (e.g. as discussed above: transport cost, administrative cost, access to other services). The relative benefits of each of these motivations tend to be conflated in some case studies therefore this paper aims to highlight these issues in Chinese inland port development and compare them to experiences in other countries.

A key component of the discussion is the role of the public sector in the development process (Wilmsmeier et al. 2011; Notteboom and Rodrigue 2005; Bergqvist 2008). Ng and Gujar (2009a\&b) addressed centrality and intermediacy (Fleming \& Hayuth 1994) and how they can be affected by government policy. Recent research has suggested that developments driven by the public sector due to motivations of regional development can run the risk of over-supply (Notteboom \& Rodrigue 2009a; Rodrigue at el. 2010; Wilmsmeier et al. 2011; Monios \& Wilmsmeier 2012). In addition, public subsidy for infrastructure development cannot guarantee the financial viability of the site if the economics of intermodal operation cannot compete with incumbent road hauliers.

Notteboom \& Rodrigue (2005) characterised inland terminals and load centres as active nodes in shaping the transport chain. Wilmsmeier et al. (2011) drew on this approach, utilising insights from industrial organisation to examine how different institutional frameworks reveal nuances in the different kinds of integration between inland ports and seaports. They introduced a conceptual approach to inland terminal development, contrasting Inside-Out development strategies (land-driven e.g. rail operators or public bodies) with those that are pursued Outside-In (sea-driven e.g. port authorities, terminal operators). While not all sites can be classified solely as one or the other, this broad conceptual distinction highlights conflicting strategies and the importance of port investment if an inland port is to establish 
successful port container shuttles (Monios \& Wilmsmeier 2012). The model will be used in this paper to enable a discussion of emerging trends as well as an international comparison.

\section{Data and methods}

The methodology is based on qualitative analysis of secondary data. The first step was to identify sites from the literature and discussions with industry and academic contacts. Once the sample of inland ports was identified, the data collection proceeded according to the guidance of the theoretical framework; thus data were collected on the ownership and investment model, customs clearance processes, rail services and logistics provision at each site in the sample.

Obtaining the required data was not a straightforward process as there is no individual database providing all necessary information on infrastructure, operational models, development strategies, traffic flows, shipping costs and so on. Data were therefore collected from various secondary sources such as internet websites, company publications, news sources, press releases, academic and industry literature and email contact. For example, official press releases from relevant Chinese government bodies like the Ministry of Transport and the General Administration of Customs provide national-level aggregates of international trade value, infrastructure investment and traffic flows, while the company websites and publications of inland port operators supply the physical, organisational and operational details of each site. In addition, supplementary information was obtained from industry publications such as those produced by the China Port and Harbours Association.

The data were reviewed several times, then organised and reduced by collating evidence in a matrix based on the theoretical framework (Table 1). Data gaps were identified and filled by follow-up emails as well as further data collection via desk research. 
The data were first analysed spatially, to establish the geographical distribution of inland ports in China and their relation to major seaports, before the two institutional issues of customs reform and intermodal transport development were considered. This approach is drawn from the changing focus in mature systems, from customs clearance (which was relevant in Europe in the 1960s but now relevant primarily in developing economies) to intermodal transport (which is becoming a popular topic in developed economies for cost purposes but also to reduce emissions).

\section{Results}

\section{Geographical distribution of inland ports in China}

The geographical distribution of inland ports in China is concentrated mainly in three clusters: the Northeast cluster, exclusively invested by the port of Dalian, the Central and West cluster led by the port of Tianjin and the Southeast cluster cooperating with the ports of Ningbo and Xiamen (see Figure 1). 


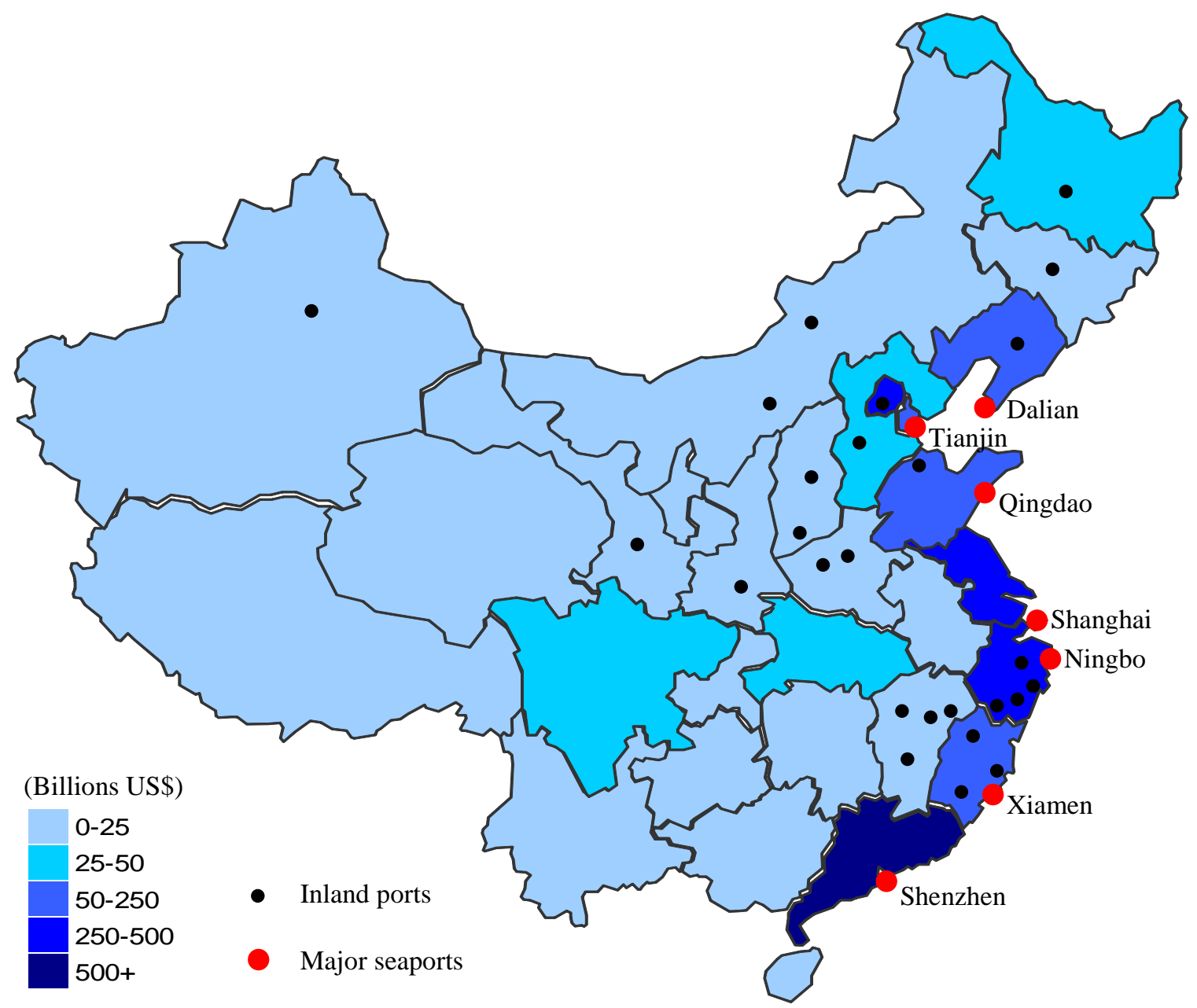

Fig. 1 International trade ${ }^{*}$ and inland port distribution in Mainland China

Note ${ }^{*}$ : All 31 provinces and municipalities from Mainland China have been classified into 6 categories according to their international trade (both export and import) value

Source: authors, based on data collected from General Administration of Customs (2010)

Concentration of inland ports in each cluster varies depending on the economic nature of each region. For example, there is still no inland port developed yet in Guangdong province. Guangdong is the most developed region in China with the highest international trade value of US\$785 billion in 2010, and firms in this area are highly concentrated with convenient connections to the ports of Shenzhen and Hong Kong, the dominant container ports in both China and East Asia. Similar to Guangdong Province, the port of Ningbo has more than 50\% 
of its throughput contributed by neighbouring cities. In contrast, the ports of Tianjin and Qingdao have a large overlapping hinterland with more than 12 provinces. Most provinces are less developed and none of them have yet reached US\$ 50 billion of international trade value. As a result, competition between these two ports is more serious than ever and inland ports in this region are often utilised as a marketing strategy, being located at some potentially strategic locations. Northeast China is traditionally under the exclusive control of the port of Dalian. However, in facing the challenge of rapid growth of smaller neighbour ports (Lu \& Chang 2013), Dalian port has also made significant investment in developing inland ports in that region. Moreover, as land and labour become more expensive in coastal provinces, some industries are beginning to migrate inland, supported by government investment in infrastructure and tax incentives for businesses (He \& Wang 2012).

Table 1 lists a sample of 18 major inland ports connected to the ports of Dalian, Tianjin and Ningbo, the dominant seaports in each of the three geographical clusters identified in Figure 1. 
Table 1 List of inland ports connected to the ports of Dalian, Tianjin and Ningbo

\begin{tabular}{|c|c|c|c|c|c|c|}
\hline Seaport & Inland port & $\begin{array}{c}\text { Distance } \\
\text { rail } \\
(\mathbf{k m})\end{array}$ & $\begin{array}{c}\text { Distance } \\
\text { road } \\
(\mathrm{km})\end{array}$ & $\begin{array}{c}\begin{array}{r}\text { Onsite rail } \\
\text { connection }\end{array} \\
(\mathrm{Y} / \mathrm{N})\end{array}$ & $\begin{array}{c}\text { Type of rail } \\
\text { freight service }\end{array}$ & $\begin{array}{c}\text { Inside- } \\
\text { Out or } \\
\text { Outside- } \\
\text { In }\end{array}$ \\
\hline \multirow[t]{3}{*}{ Dalian } & Haerbin & 911 & 946 & $\overline{\mathrm{Y}}$ & Fixed Schedule & Outside-In \\
\hline & Changchun & 704 & 687 & $\mathrm{Y}$ & Fixed Schedule & Outside-In \\
\hline & Shenyang & 394 & 315 & $\mathrm{Y}$ & Fixed Schedule & Outside-In \\
\hline \multirow[t]{9}{*}{ Tianjin } & Beijing-Chaoyang & - & 130 & $\mathrm{~N}$ & - & Outside-In \\
\hline & Beijing-Pinggu & - & 130 & $\mathrm{~N}$ & - & Inside-Out \\
\hline & Erlianhaote & 979 & 828 & $\mathrm{Y}$ & Block Train & Outside-In \\
\hline & Zhengzhou & - & 704 & $\mathrm{~N}$ & - & Inside-Out \\
\hline & Shijiazhuang & - & 400 & $\mathrm{~N}$ & - & Outside-In \\
\hline & Baotou & 986 & 805 & $\mathrm{Y}$ & Shuttle Block Train & Outside-In \\
\hline & Huinong & 1500 & 1298 & $\mathrm{Y}$ & Fixed Schedule & Outside-In \\
\hline & Xi'an & 1301 & 1157 & $\mathrm{Y}$ & Block Train & Inside-Out \\
\hline & Dezhou & - & 200 & $\mathrm{~N}$ & - & Outside-In \\
\hline \multirow[t]{6}{*}{ Ningbo } & Jinhua & - & 300 & $\mathrm{~N}$ & - & Outside-In \\
\hline & Yiwu & 317 & 260 & $\mathrm{~N}^{*}$ & Fixed Schedule & Outside-In \\
\hline & Shaoxing & - & 108 & $\mathrm{~N}$ & - & Outside-In \\
\hline & Quzhou & 441 & 366 & $\mathrm{~N}^{*}$ & Block Train & Outside-In \\
\hline & Shangrao & 552 & 424 & $\mathrm{~N}^{*}$ & Fixed Schedule & Outside-In \\
\hline & Yuyao & - & 70 & $\mathrm{~N}$ & - & Outside-In \\
\hline
\end{tabular}

*Note: The inland ports of Yiwu, Quzhou and Shangrao all have rail connections less than $10 \mathrm{~km}$ away but not onsite

Source: compiled by authors from various data sources, including websites, company information and personal correspondence 
All sites in the sample offer customs clearance and logistics services. This represents a contrast to inland ports in Europe and the United States, which differ in their service portfolios. Some sites are merely intermodal terminals with no other service provision, and customs clearance is offered at some sites and not others.

\section{Customs clearance}

Improving the convenience of customs clearance operations has been essential to inland port development in China. Before customs reform began in 2006, customs clearance involved a complicated process in which shippers/receivers had to declare to both local and port customs while cargo had to be inspected twice as well. It led to a signification reduction in trade efficiency and unnecessary increases in time and transaction costs. Some locations, for example Beijing-Chaoyang Inland Port, were able to operate a simplified customs procedure, in that case based on a special agreement between the customs authorities of Beijing and Tianjin. However, since September 2006, inland ports in China have benefited from the customs reform policy of the General Administration of Customs.

In accordance with this policy, there are currently two customs clearance models applied in inland port operations: Inter-Customs and Inland Port (see Figure 2). The former is applicable to most situations once agreements have been made across customs jurisdictions, while the latter is more appropriate for using inland ports as it was specifically developed by the customs authority of Tianjin to support local port development. As defined by the General Administration of Customs, the Inter-Customs model means that eligible shippers and receivers can declare their cargo to any of the local customs authorities and, during this time, apply for cargo inspection and release at the port through which their cargo will be shipped as import or export (General Administration of Customs 2006). Eligibility applies to companies with an A or AA certificate, which is a credit rating by customs authorities for those 
companies that have (a) been registered more than two years, (b) achieved at least US $\$ 500,000$ import and export value (US\$1,000,000 required before $1^{\text {st }}$ April 2008), and (c) a history of observing customs laws, rules and regulations.

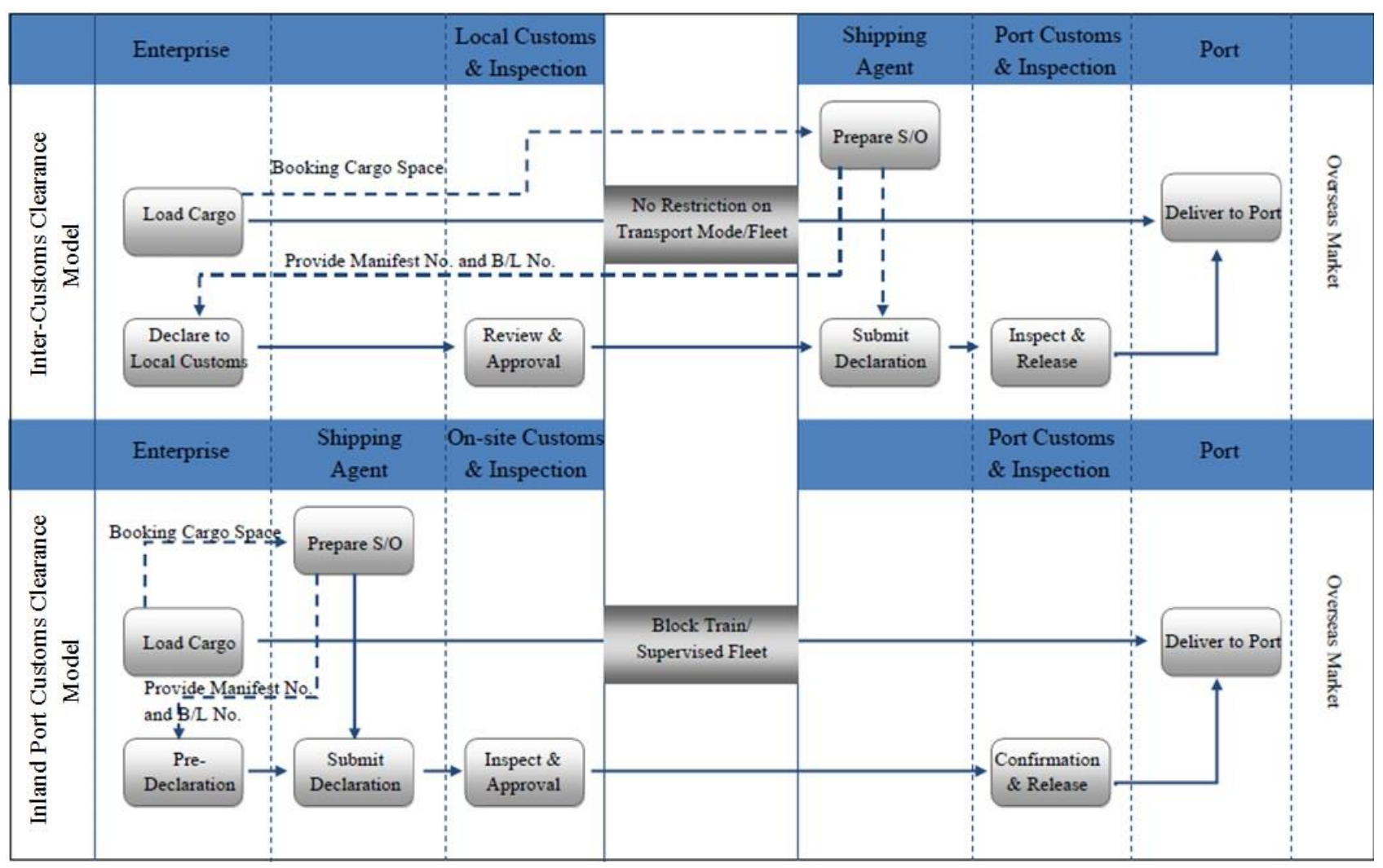

Fig. 2 Comparison of the Inter-Customs and Inland Port customs clearance models

Source: authors

By contrast, the Inland Port model offers shippers/receivers a 'one stop' clearance service through onsite customs declaration, inspection, cargo space booking and all other relevant services. Once approved, cargo will be delivered to the port securely by using block train services or a supervised road fleet. There is no further inspection needed at port customs, but an e-documentation check instead. Another advantage for using the Inland Port model is that tax reimbursement can be done as soon as the cargo has been released from the inland port, 
rather than waiting for the release confirmation from port customs, which can take up to seven days with the Inter-Customs model (Shi 2009).

\section{Intermodal transport}

Due to the geographical nature of China, transport distances between inland ports and seaports vary widely, with the result that both road and rail play significant roles.

Road is the dominant transport mode in China and it accounts for nearly $90 \%$ of inland container movements between seaports and the hinterland. For most inland ports located less than $500 \mathrm{~km}$ away from seaports, road transport has been used extensively due to its advantages of convenience, flexibility and price. Typical examples include the inland ports of Shijiazhuang, Beijing-Mafang and Shenyang. For inland ports with a transport distance of between $500 \mathrm{~km}$ and $1000 \mathrm{~km}$, road transportation still shows great attractiveness to shippers with small volumes but high demand on transit time. For instance, to transport a 40 foot container from Dalian to Changchun (about 700km) generally costs about $\$ 630$ and $\$ 440$ by road and rail respectively. However, clients have to pay another $\$ 110$ for the delivery of cargo from the inland port to their local warehouse (China Port and Harbour Association 2010). Thus the cost advantage of using rail services for long distance transportation has been eroded by the cost of the "last mile". In terms of transit time, there is no significant advantage for road transportation, but it does not have to wait for the next available train service, which often involves additional delays.

China's railway network is the third largest in the world, following the USA and Russia, and between 1978 and 2010 its annual freight traffic increased from 535 to 2,764 billion tonne kilometres (Wang et al. 2012). As China's network density is far below that of other countries, the traffic density per $\mathrm{km}$ is therefore extremely high, leading to capacity constraints and demand suppression (World Bank 2009). As a result of political decisions to 
ration scarce track capacity in favour of strategically important bulk traffic, containers represent only around $10 \%$ of tonne-kms in China (World Bank 2009). However, the rail network is in the process of enormous expansion. The MLRNP (Mid to Long-Range Network Plan (first published in 2004 and revised in 2008 [MOR, 2008]) announced an intention to expand the network length from $72,000 \mathrm{~km}$ to $120,000 \mathrm{~km}$ by 2020 . This infrastructure development was elaborated in the eleventh Five Year Plan (2006-2010), along with a goal to triple container movements by rail by 2010 .

At a national level, the MOR (Ministry of Railways) retains overall control of planning and financing railways in China. However, all rail services are operated by one of the 18 regional railway bureaux, within each of which the infrastructure and operations are vertically integrated. It has been argued that as the current multi-level railway network has evolved from the earlier single national network, the top-down financing structure managed at the national level does not always align with the bottom-up regional development strategies (Wang et al. 2012). System reforms (in particular ways of introducing competition) have been mooted over the years (e.g. Wu \& Nash 2000; Xie et al. 2002; Pittman 2004; Rong \& Bouf 2005); recently Pittmann (2011) suggested that in a country with large distances and large volumes (comparable to the United States), parallel competition could be introduced in China through multiple closed systems. In 2003 the CRCTC (China Rail Container Transport Company) was formed as a joint venture between the MOR and the 18 regional rail bureaux, to focus on developing scheduled container services on high density intermodal corridors rather than the predominant wagonload approach taken in the past, including service improvements such as reducing the lead time for delivering a wagon to a shipper.

Port authorities in China are anxious to set up intermodal rail connections with inland ports. It has also been encouraged by both local and central governments, where the former often provide subsidies to operators of block train services while the latter focus on the 
coordination between the Ministry of Transport and Ministry of Railway, as well as the regional rail bureaux below the central level. However, there are still several challenges to be faced in future development.

First, integrating inland and maritime networks is difficult. This refers not only to infrastructure development, but also seamless information exchange and schedule coordination. Second, service frequency needs to be increased further in order to reduce the waiting time at both ends of the intermodal transport chain. Third, the low containerisation rate in rail transport (Loo \& Hook 2002) has led to the lack of enough cargo to satisfy the minimum requirement of running block train services - at least 36 wagons/72 containers per service is required to achieve economies of scale. Table 1 lists the different kinds of rail service currently operating between the three ports and their inland ports studied in this paper. The fourth issue relates to the empty repositioning costs resulting from the trade imbalance of China's export-dominated economy (Theofanis \& Boile 2009). This problem must be addressed through more active involvement of shipping companies in inland port operations. However, competition between transport corridors may challenge such attempts at integration. For example, the city of Zhengzhou has two inland ports. One is with Tianjin (Henan Highway Port Bureau, road transport only), as noted in Table 1, while another inland port (not discussed in this paper: Zhengzhou International Logistics Park) is located $1.5 \mathrm{~km}$ away. This second inland port has its own rail connection but to the port of Qingdao.

Rail connections are particularly important for those inland ports located in central and western China with longer transport distances to/from seaports. Significant infrastructure developments on railway connections between inland ports and seaports have been made in recent years. Most inland and coastal cities are well connected by rail freight services and these services have been further extended to on-dock sites at 10 major ports (China Port \& Harbours Association 2011a). Moreover, a 50-year joint venture has been established (34\% 
owned by CRCTC) to construct or upgrade 18 "pivotal rail container terminals" at coastal or inland locations to support the container services already discussed. Half of these were already in operation by the end of 2010. Two shipping lines (CMA CGM and Zim) own 8\% each of this undertaking, therefore elements of an Outside-In strategy are present, aiming to provide greater coordination between maritime and overland container movements. It can be expected that container flows to/from ports will be channelled along these upgraded lines, giving a competitive advantage to those inland ports on these routes.

The utilisation rate of intermodal rail freight services between inland ports and seaports is not as good as might be expected. For example, 1.6 million TEU were transported by rail between seaports and inland ports in 2010, which accounts for only $1.1 \%$ of the total container throughput of 145 million TEU handled by Chinese seaports (see Table 2). Moreover, for the major ports in China, shares of sea-rail intermodal contribution vary from $0.2 \%$ to $5.5 \%$ depending on the geographical and economic features of their hinterland distribution. The port of Dalian exhibited the highest proportion of $5.5 \%$ because, as Northeast China is the traditional heavy industrial base, it has the most well-developed railway connections, both infrastructure and fixed schedule block train services. Tianjin and Qingdao together account for around 2\% due to the geographical nature of their hinterland, whereas the figure is less than $1 \%$ in Shanghai, Shenzhen and Ningbo. Comparatively, these figures are far behind the average rate of $15-25 \%$ in leading ports in the US and Europe (e.g. Los Angeles, Rotterdam and Hamburg). 
Table 2 Container throughput on intermodal services to/from major ports in China, 2010

\begin{tabular}{cccc}
\hline Seaport & $\begin{array}{c}\text { Port throughput } \\
(000 \mathrm{TEU})\end{array}$ & $\begin{array}{c}\text { Intermodal contribution } \\
(000 \mathrm{TEU})\end{array}$ & Percentage share \\
\hline Shanghai & 29,070 & 72 & $0.2 \%$ \\
Shenzhen & 18,250 & N/A & N/A \\
Ningbo & 13,147 & 34 & $0.3 \%$ \\
Qingdao & 10,262 & 181 & $1.8 \%$ \\
Tianjin & 10,086 & 191 & $1.9 \%$ \\
Dalian & 5,262 & 291 & $5.5 \%$ \\
\hline Total in China & $\mathbf{1 4 5 , 0 0 0}$ & $\mathbf{1 , 6 2 0}$ & $\mathbf{1 . 1 \%}$ \\
\hline
\end{tabular}

Source: China Port \& Harbours Association, 2011b

It was noted earlier in the paper that containers moved by road under customs bond do so by a special fleet. Therefore even the inland ports that are road-based still have a degree of integration in the link between the seaport and the inland port. The road movement is handled by a company that has been set up specially to perform this task, as a kind of internal movement that is cheaper and simpler than contracting a third-party haulier. This system means that, having completed all the customs and export paperwork at the inland port, the truck can take the container to the port and drop it immediately, rather than spend up to seven days there completing the necessary administration tasks.

\section{Comparisons with other continents}

Different models of inland port development relate partly to the motivations for using the site. One motivation is to reduce transport costs by bundling flows to achieve economies of scale on key routes, whereas another aim is to reduce transaction costs by moving administrative activities such as customs inland. The inland port may be far inland or it may be close to the port, thus serving purely to reduce costs associated with congestion-related delays, both for the port operator and the shipper. It was seen in this paper that, as well as 
distant inland ports, close-range sites are being used in China to relieve port congestion and save time for the shipper by transferring administrative tasks to a location not far from the port, linked by regular truck shuttles.

Related services such as containerisation are also important to inland port operations. Containerisation can be a problem in developing countries where trade is based more on raw materials and bulk movements therefore containerised trade and all the attendant services are less developed. Shippers may have to drive a load to the port and wait a significant amount of time to get it containerised before it can be loaded on the ship. All of these costs reduce the competitiveness of exports from such countries. Meanwhile, containerisation of bulk cargos (e.g. grain) has emerged as a new tendency in enlarging the container transport market (Rodrigue and Notteboom 2011) and it has been utilised in the north east of China for services to the port of Dalian. Container management can also be a problem for developed countries with long distances. For instance, in the USA shipping lines are reluctant to send maritime containers far inland as they cannot guarantee an export load for the return journey (as the USA is an import economy) (Monios \& Lambert 2013). So they tend to transload at the port from 20ft/40ft deepsea containers into 53ft domestic boxes (Notteboom \& Rodrigue 2009b).

Inland customs clearance is a more significant issue in China than for European or North American inland ports. Inland Clearance Depots (ICDs) appeared in Europe from the 1960s (Garnwa et al. 2009), as the container revolution and motorway development changed the transport geography of freight distribution from the coast to inland centralised locations. Specifying an inland location on the bill of lading and clearing customs inland were therefore attractive to shippers. Now, with the ease of electronic documentation, shippers can clear customs at a point of their choosing with less impact on the practicalities of their business. As with the A or AA certification in China, the Authorised Economic Operator (AEO) system in 
Europe allows operators thus designated to proceed without the need for physical inspection. In addition, the union of customs across the European Union in addition to a currency union across much of Europe have simplified the process enormously. In the United States, as a single country, customs jurisdiction and currency are unified; moreover, as $89 \%$ of freight is domestic (FHA 2010), international freight movements are less integrated with purely domestic flows and thus have less incentive to clear customs inland.

In both Europe and the United States, joint customs jurisdictions and a single currency make customs clearance procedures simpler, faster and cheaper, as fewer organisations are involved and currency conversion expenses are eliminated. In countries where this is not the case, being able to perform administrative duties (including but not limited to customs) inland can produce significant cost savings. Comparisons can be made with Africa, particularly landlocked African countries where additional barriers exist between the port and the hinterland location (Adzigbey et al. 2007). Being able to clear customs later (for imports) can improve cash flow by paying import duties when the goods arrive inland (or more specifically, when they are taken from the inland port, giving the potential for extended storage, because the fee is paid only when the goods are required). The downside of this system is that funds may be tied up in customs bonds, but attempts are being made to establish an authorised importer system whereby reporting requirements are reduced and a bond may not be requested (Arvis et al. 2011). Europe and the United States have more mature transport and logistics sectors, thus firms tend to be much larger, with higher cash flow. In Africa and China there are more small shippers who can gain from streamlined customs and administrative procedures.

The geography of China means that its potential to develop intermodal transport has similar advantages to North America, where rail is competitive with road due to long distances and the ability to run long trains with double stack capacity. In particular, the 
vertical integration of rail in the United States means that transaction costs are lowered and investment in rail infrastructure is more directly related to service development and operational requirements. Moreover, as the economies of scale are greater in the United States, rail operators focus on their core business of transportation, running large sites with rail throughput exceeding 100,000 TEU annually (Monios \& Lambert 2013). Containers are then taken elsewhere for logistics activities, and "co-location" of transport and logistics activities is less common (Rodrigue \& Notteboom 2010).

In Africa, road remains dominant because even inland ports that have a rail connection have struggled to attract traffic due to a number of reasons (Nathan Associates 2011; Kunaka 2013). Despite long distances, inefficient rail operations and poorly maintained infrastructure mean that, first, the rail costs are much higher than they would be elsewhere and second, even when they are lower, the inconvenience and unreliability outweigh the savings in transport costs, as more time has to be built into the supply chain and higher inventory levels are required for stock buffering (Arvis et al. 2007). The analysis in this paper has shown that similar fragmentation and lack of service provision are preventing rail competing with road in China at both short and medium distances.

Inland port development in Europe is often subsidised on the basis of benefits to be gained from modal shift of freight from road to rail, whether societal benefits from reducing pollution and congestion or benefits for industry such as reducing transport costs for shippers (Wilmsmeier et al. 2011). However, the economic feasibility of intermodal transport remains challenged due to short distances, inability to double stack and the inevitable fragmentation resulting from the multiple institutional jurisdictions covered by the European rail network. In order to attract enough custom to fill trains, many operators offer a door-to-door service, often rebranding themselves as logistics providers and taking more direct involvement in container management through different strategies (Monios \& Wilmsmeier 2012). However, 
fierce port competition has resulted in overlapping of market coverage thus splitting potential scale economies. This paper has shown that some inland ports in China have dedicated agreements with specific ports, while others have multiple agreements; it could therefore be the case that competition will dilute the potential consolidation of traffic. As a consequence, successful intermodal transport may be challenged except on longer routes with double stack access (like in the USA).

\section{Applying the conceptual model: drivers and direction of inland port development in}

\section{China}

\section{Inside-Out}

Those inland ports that have been classified in this paper as Inside-Out are often named as bonded logistics parks or export processing zones, referring to facilities that are developed by municipalities for the purpose of improving local export and domestic trade competitivenss through a sophisticated logistics industry. They tend to be located near cities with strategic geography and the convergence of major motorway and rail connections. Inside-Out inland ports tend to have a high incidence of domestic traffic, which is particularly relevant in a country with the geographical size of China. In addition, due to the nature of the export-led economy, on-site customs and other services are always essential to simplify these processes.

As illustrated in Figure 3, Inside-Out inland ports, under the approval of the State Council of China, are initially planned by provincial or municipal governments that utilise one central place for all types of transportation activities and value-added services needed by exporters and local traders for shipment of their goods. As the inland port developing agency, a regulatory body named "administration of district" is responsible for the site layout planning, infra- and superstructure construction, maintainance and management, etc. Coordination with various ministries of central government (e.g. Ministry of Railways, Ministry of Transport 
and Administration of Customs, etc.) is also esstential. Moreover, in attracting more engagement of private or foreign capital, a series of supporting policies mainly granted by local government regarding land provision, tax deductions, financial support and utility subsidy could be offered to the proposed companies.

A lack of logistics capacity has been found to be a restricting factor on trade in China (Beresford et al. 2012). Inside-Out inland ports (e.g. Xi'an International Trade \& Logistics Park) are thus more focused on logistics than the Outside-In model (see next section). As well as bonded warehousing and centralised customs declaration, they offer facilities for distribution, information management and processing, particularly related to exports, as well as intermodal transport access in some cases. Beyond regular logistics functions, they are more likely to be part of a larger site including an export processing zone. To improve relations with the seaport, preferential taxation policies and port charges will also be in place.

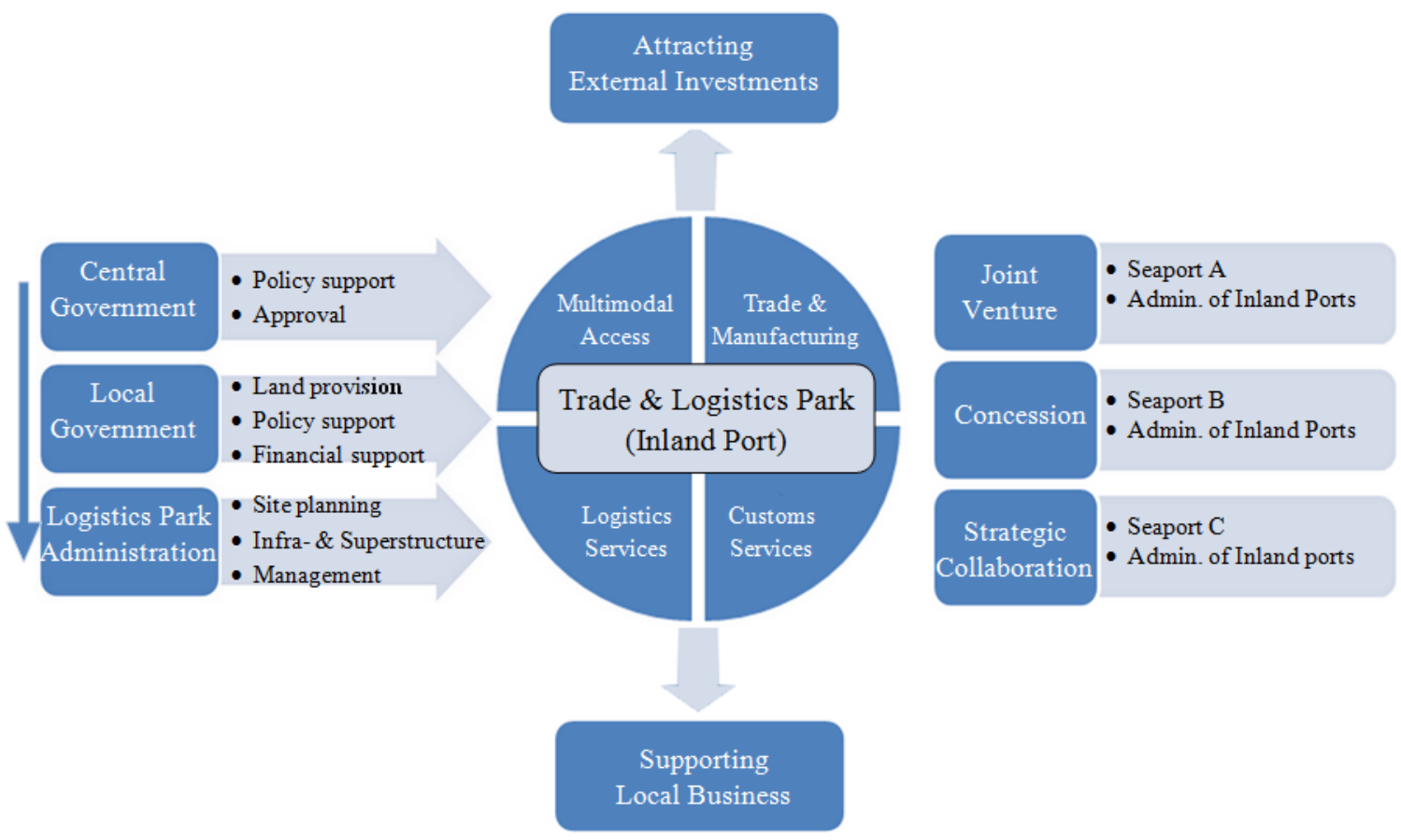

Fig. 3 Application of the Inside-Out institutional framework to Chinese inland ports Source: authors 
Within this category, integration between inland ports and seaports may be implemented through a concession agreement, strategic collaboration or even a third-party company through a joint venture. It means that the inland corridor for cargo transportation from cities to international markets is not necessarily linked with a single seaport, but multiple seaports may be connected. For instance, Xi'an International Trade Logistics Park has built partner relationships with the ports of Tianjin, Qingdao, Lianyuangang and Shanghai since 2005. Only one (with Tianjin) is a joint venture; the other three are collaboration agreements. However, none of the ports have invested in infrastructure or superstructure development.

\section{Outside-In}

The majority of inland ports analysed in this sample are seaport-driven, thus in this paper they have been classified according to the Outside-In model. Within the context of this concept, inland ports are used by seaports as a tool in securing their hinterland control. Like Inside-Out inland ports, the intended functions of such inland ports cover on-site customs clearance service and bonded warehousing, consolidation and distribution activities (and other low-value-added services) and in some cases cargo transhipment from rail to road. However, in contrast to the Inside-Out model, the size of Outside-In inland ports tends to be relatively small. This is because they are developed with the primary purpose of improving port access rather than logistics capability. For example, local governments in Zhejiang province only offer limited policy support (e.g. providing land at a discounted price in addition to tax deduction) to inland port development, but provide more government subsidies to those companies that use them. In so doing, traffic flows gathered at these inland ports would be assigned to the port of Ningbo, rather than going through Shanghai. 
As with fully municipality-developed Inside-Out inland ports, significant effort has been made by local governments in supporting port-driven inland port development, including discounted land, tax deductions and inland port usage subsidy. For example, Jinhua and Quzhou inland ports received 50\% and 38\% reductions on the purchase price of the land in 2002 and 2007 respectively; the Business Tax has also been exempted for the first five years of operation. In addition, for firms that use these two inland ports for cargo export, there is also a subsidy from local government that US\$ 3 per TEU will be given when a company ships more than 1000 TEU per year. This subsidy would increase by an extra US\$1.5 per TEU with every thousand TEU (Fujian Port Office 2010).

In respect of the institutional framework of the Outside-In model, as shown in Figure 4, it is more complicated than the Inside-Out model. It is not necessary to ask approval from central government, but is often instead pursued by a commercial collaboration between port authorities, regional railway administrations and local municipalities. It will be developed by a port authority either through a joint venture with local government and a state-owned company (full line), or cooperating with the local government and railway administration (broken line). The former is generally road-based (close and mid-range), located within a logistics park through concession agreement or a newly developed site, while the latter is always rail-based (mid-range and distant), including an intermodal terminal and container yard for the transloading operations. Unlike some examples in Europe, in China the OutsideIn model is only developed by port authorities; the port terminal operator does not drive the development. 


\section{Inland Ports}

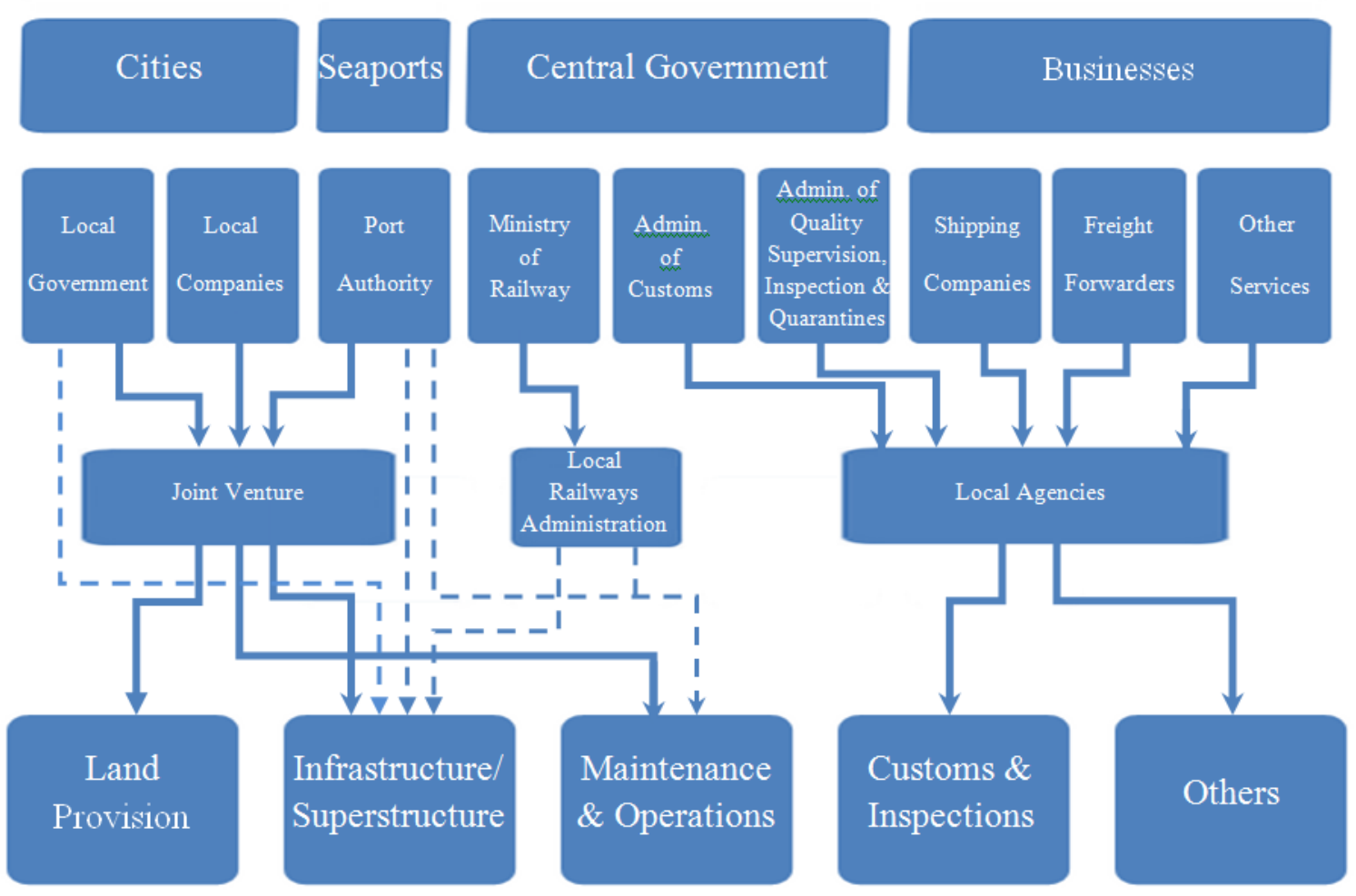

Fig. 4 Application of the Outside-In institutional framework to Chinese inland ports

Source: authors

In addition, generally speaking, there should be only one inland port located in each city so that transportation of export and import cargos is exclusively assigned with the inland corridor between the inland port and the invested seaport. However, in some cases, in one city there will be more than one inland port invested by different ports. For example, three different institutions all from Zhengzhou have signed strategic collaboration agreements with the ports of Tianjin, Qingdao and Lianyungang respectively to develop inland ports together. It reveals the high level of competition in this region where hinterlands overlap rather than being captive, as in the case of Dalian in the north east of the country. Such excessive interport competition has the potential to split economies of scale and reduce the economic viability of rail transport on certain corridors. 


\section{Directional development of inland ports across different spaces}

Using the directional development model, Monios \& Wilmsmeier (2012) found that with the Outside-In model, port actors can be motivated to integrate inland to overcome operational issues such as congestion, whereas strategic involvement for purposes of hinterland capture is less successful. Port actors (whether port authorities or port terminal operators) experience difficulty extending their influence beyond the port perimeter (de Langen 2008), therefore Outside-In development of inland ports is more difficult. However, they also found that Inside-Out strategies for logistics poles do not always align with the operational or strategic aims of port actors, meaning that while domestic container flows (or intra-European, in the case of central European inland ports) may be attainable, establishing regular shuttles between ports and inland locations proves difficult, as the port is not motivated to overcome the various operational and institutional difficulties involved. Over time, as different actors become involved with a site and information is shared between port and inland actors, these conflicts may be overcome, but they can be avoided in the development process if the intended function and traffic sources for a site are clearly identified at the outset.

The complexity of the governance system for inland port development in China has been noted by previous authors (Beresford et al. 2012). By contrasting the Inside-Out and OutsideIn strategies in this paper, this complexity can be examined in more detail. Looking first at the Inside-Out model, in which central government policy encourages inland port development but the actual development is scaled at the local level, a number of different subsidy policies are related to different aspects such as land purchase, infrastructure connections, building of superstructure and the subsequent operation of the site itself. In addition, many permissions must be obtained from central agencies such as customs and quarantine. The Outside-In model is more complex, because while the seaport desires to use 
the inland port to secure its hinterland or compete for an overlapping hinterland, the development remains scaled at the local level, therefore various kinds of contracts, investments or joint ventures may be agreed between the seaport and the inland port, which again must fit into the web of agreements, permissions and investments from central agencies.

Therefore, while some involvement from seaports and central government is necessary in all cases for a successful inland port, due to the complex institutional structure, the development, whether Inside-Out or Outside-In, is always scaled at a local level. It is the municipality that draws together the various institutions such as national and regional customs, national and regional rail authorities, and the other permissions and services necessary. Most importantly, the land provision or development approval is by the local government. Previous research has shown that while an increasingly regional perspective is being pursued in China, there is no formal regional government, and competing local governments do not always cooperate to achieve the regional coordination encouraged by central government policy ( $\mathrm{Li} \& \mathrm{Wu} 2012)$.

The strategic (to compete with other ports) and operational (to improve access to the port for users) aims of the seaport do not always align with the policy aspirations of central government or the planning strategies of local governments. This strategy misalignment between local and central scales is common across continents. Ng \& Cetin (2012) suggested that Inside-Out development is the common model in developing countries, as opposed to Outside-In in developed countries, whereas Monios \& Wilmsmeier (2012) argued that InsideOut development is common in developed countries also. The cases in this paper have shown that both models are prevalent in China, while Outside-In were the most common in this particular sample. This may be explained partly by the fact that domestic container traffic, often a key market segment for sites developed on the Inside-Out model, remains only a tiny 
sector of the rail market in China. Another reason may be that central government policies to develop central and western China are still in their early stages. More Inside-Out inland ports may appear in the Chinese hinterland as these policies are expanded. Finally, the current prevalence of the Outside-In model can be explained in more depth by understanding both the market structure and geographical distribution of China's container port industry.

It was observed in the introduction that the East Asian hinterland model has previously been categorised as coastal concentration with low inland coverage (Lee et al. 2008). The sailing distance between pairs of Chinese ports within the same economic cluster are very short, resulting in significant hinterland overlap and intensified inter-port competition. Figure 5 demonstrates the emergence of the Chinese container port industry by addressing its growth in investment and container throughput since 2000. China's international trade value has also been included due to its high relevance to both economic growth and port traffic generation. Starting with a base level at the year 2000, the pace of investment growth in coastal port infrastructure shows a significant increase in relation both to the growth of container throughput and international trade value. Investment in 2011 reached US\$ 15.9 billion, which is about eleven times the total investment in 2000, while growth of the latter two categories was far behind this pace, increasing by a factor of about seven. 


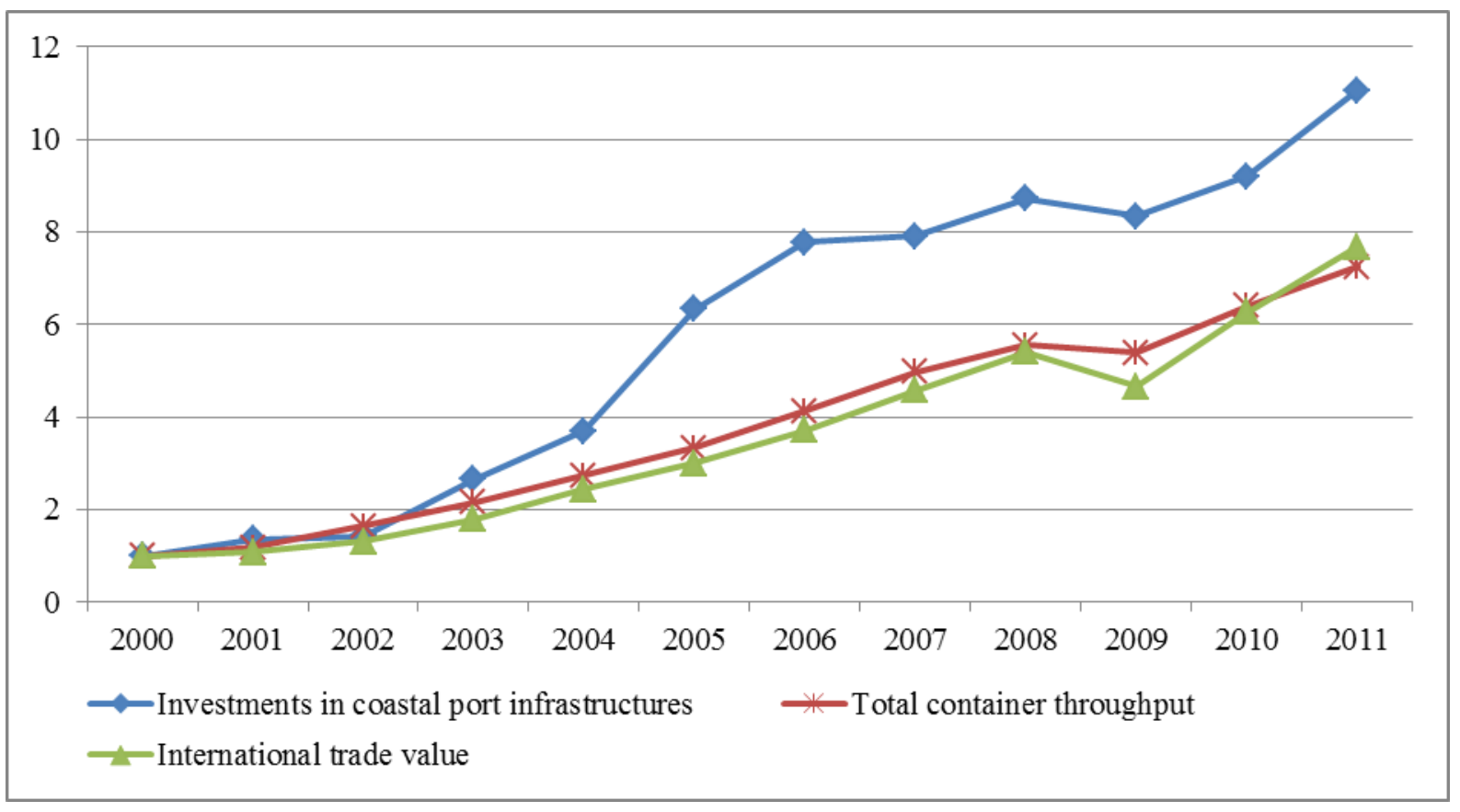

Fig. 5 Comparison of container throughput, trade value and investment in China's container port industry

Source: authors, based on Ministry of Transport (various years)

This surge in investment in port infrastructure over the last ten years, which was primarily intended to facilitate the expansion and improvement of cargo handling capacity, has unexpectedly resulted in excessive inter-port competition. Cullinane and Wang (2012) argued that this investment may not be sustainable and could lead to an inefficient utilisation of port resources if the market environment were to change fundamentally. It is especially true for China as its export-oriented economy faces the simultaneous threats of a rapid rise in domestic labour cost and a contraction in global demand. It is therefore essential for port authorities and terminal operators to maintain their growth by securing traffic flows, balancing the dependency on exports and/or enhancing their hinterland supply. The latter would be an easier and more efficient choice, which goes some way towards explaining the observed strategy of investing in inland ports. 


\section{Conclusion}

The utility of the conceptual distinction utilised in this paper is to clarify potential conflicts of strategy between port and inland actors that may hamper successful operation, particularly consolidating traffic on intermodal routes. For example, wagon and container configurations for maritime flows (the primary interest of port actors) may not align with the operational requirements of domestic flows (see comparison with USA, where the majority of container movements are domestic, as may be the case in the future in China). In particular, Inside-Out developments without port investment experience greater difficulty establishing rail shuttles with ports than Outside-In arrangements, in which the port has an interest in the site. It was noted in the intermodal discussion that the railway bureaux have experienced difficulties establishing intermodal services, which supports this view. The new joint venture linking key terminals with ports is an attempt to overcome this problem, with some investment from shipping lines (but, interestingly, not ports). Container flows can be expected to follow this investment and those inland ports without direct involvement from either ports or shipping lines may find competition difficult, however, it is too early to observe the results of these actions.

The potential conflict between Inside-Out and Outside-In models could lead to a complex situation with inland ports competing for cargo within the same location, eroding economies of scale on intermodal routes and decreasing the return on public investment. As inland port development in China remains in its early stages, a stronger central approach to subsidising inland port development could improve this situation, however, it is recognised that across such a large area a top-down approach may be unattractive or simply unworkable. Moreover, once start-up subsidies expire, shippers and other decision makers will choose the cheapest or most attractive route for their cargo and uncompetitive sites will lose business. A second generation of inland ports may then begin to appear to fit into the new transport geography of 
freight distribution in the Chinese hinterland, thus following the pattern already observed in Europe and North America. The paper has therefore revealed that China's freight geography, previously characterised as coastal concentration with low inland penetration, has been at least partially transformed to a model of hinterland integration more recognisable in Europe, with potential for greater landbridge development, as in North America.

\section{References}

Adzigbey, Y., Kunaka, C., \& Mitiku, T. N. (2007). Institutional Arrangements for Transport Corridor Management in Sub-Saharan Africa. SSATP working paper 86. Washington DC: World Bank.

Arvis, J-F., Raballand, G., \& Marteau, J-F. (2007). The cost of being landlocked: logistics costs and supply chain reliability. Policy Research Working paper. Washington DC: World Bank.

Arvis, J-F., Carruthers, R., Smith, G., \& Willoughby, C. (2011). Connecting Landlocked Developing Countries to Markets: Trade Corridors in the 21st Century. Washington DC: World Bank.

Beresford, A. K. C., \& Dubey, R. C. (1991). Handbook on the management and operation of dry ports. RDP/LDC/7. Geneva, Switzerland: UNCTAD.

Beresford, A., Pettit, S., Xu, Q., \& Williams, S. (2012). A study of dry port development in China. Maritime Economics \& Logistics, 14(1), 73-98.

Bergqvist, R. (2008). Realizing Logistics Opportunities in a Public-Private Collaborative Setting: The Story of Skaraborg. Transport Reviews, 28(2), 219-237.

Bergqvist, R., Falkemark, G., \& Woxenius, J. (2010). Establishing intermodal terminals. World Review of Intermodal Transportation Research, 3(3), 285-302.

Bichou, K., \& Gray, R. (2004). A logistics and supply chain management approach to port performance measurement. Maritime Policy \& Management, 31(1), 47-67.

China Port and Harbours Association. (2010). Port price study. China Ports, 8, 45-46.

China Port and Harbours Association. (2011a). Limitation of railway capacity and challenges in information exchange, Port Container Information (e-magazine), 848, 
http://www.portcontainer.cn/DocumentMore.do?command=query\&jspName=/documentsmore.jsp \&moreId=3, Accessed 15 December 2011.

China Port and Harbours Association. (2011b). Statistics of railway container transportation in China's port industry, China Ports, 1, 32 .

Cullinane, K. P. B., \& Wang, Y. (2012). The hierarchical configuration of the container port industry: an application of multiple linkage analysis. Maritime Policy \& Management, 39(2), 169-187.

De Langen, P. W. (2008). Ensuring hinterland access: the role of port authorities. Discussion paper. JTRC OECD/ITF 2008-11.

FHA. (2010). Freight Facts and Figures 2010.

http://ops.fhwa.dot.gov/freight/freight analysis/nat freight stats/docs/10factsfigures/pdfs/fff2010 highres.pdf Accessed 22 February, 2011.

Fleming, D. K., \& Hayuth, Y. (1994). Spatial characteristics of transportation hubs: centrality and intermediacy. Journal of Transport Geography, 2(1), 3-18.

Frémont, A., \& Soppé, M. (2007). Northern European range: shipping line concentration and port hierarchy. In J. Wang, D. Olivier, T. Notteboom, \& B. Slack (Eds.), Ports, Cities and Global Supply Chains (pp. 105-120). Aldershot: Ashgate.

Fujin Port Office (2010). Inland port development in Zhejiang province and its implications to Fujian, $\begin{array}{lllll}\text { Government } & \text { Research } & \text { Report, } & 25 & \text { February }\end{array}$ http://www.fiet.gov.cn/html/20080425005523/20100225/475181.html, Accessed 23 December, 2011.

Garnwa, P., Beresford, A., \& Pettit, S. (2009). Dry ports: a comparative study of the United Kingdom and Nigeria. In Transport and Communications Bulletin for Asia and the Pacific No. 78: Development of Dry Ports (pp. 40-56). New York: UNESCAP.

General Administration of Customs. (2006). The $43^{\text {rd }}$ announcement from General Administration of Customs, China, http://www.customs.gov.cn/Default.aspx?TabID=419\&InfoID=30836\&SettingModuleID=1188, Accessed 23 December 2011. 
General Administration of Customs. (2010). China Customs Statistics Year Book 2010. Beijing: China Customs Press.

Hall, D. (2010). Transport geography and new European realities: a critique. Journal of Transport Geography, 18(1), 1-13.

Hanaoka, S., \& Regmi, M. B. (2011). Promoting intermodal freight transport through the development of dry ports in Asia: an environmental perspective. IATSS Research, 35(1), 16-23.

Hayuth, Y. (2007). Globalisation and the port-urban interface: conflicts and opportunities. In J. Wang, D. Olivier, T. Notteboom, \& B. Slack (Eds.), Ports, Cities and Global Supply Chains (pp. 141156). Aldershot: Ashgate.

He, C., \& Wang, J. (2012). Regional and sectoral differences in the spatial restructuring of Chinese manufacturing industries during the post-WTO period. GeoJournal, 77(3), 361-381.

Heaver, T., Meersman, H., Moglia, F., \& Van de Voorde, E. (2000). Do mergers and alliances influence European shipping and port competition? Maritime Policy \& Management, 27(4), 363373.

Heaver, T., Meersman, H., \& Van de Voorde, E. (2001). Co-operation and competition in international container transport: strategies for ports. Maritime Policy \& Management, 28(3), 293305.

Konings, J. W. (1996). Integrated centres for the transhipment, storage, collection and distribution of goods. Transport Policy, 3(1), 3-11.

Kunaka, C. (2013). Dry ports and trade logistics in Africa. In R. Bergqvist, K. P. B. Cullinane, G. Wilmsmeier (Eds.), Dry ports: a global perspective. London: Ashgate.

Lee, S-W., Song, D-W., \& Ducruet, C. (2008). A tale of Asia's world ports: the spatial evolution in global hub port cities. Geoforum, 39(1), 372-385.

Li, Y., \& Wu, F. (2012). The transformation of regional governance in China: the rescaling of statehood. Progress in Planning, 78(1), 55-99.

Loo, B. P. Y., \& Hook, B. (2002). Interplay of international, national and local factors in shaping container port development: a case study of Hong Kong. Transport Reviews, 22(2), 219-245. 
Lu, J., \& Chang, Z. (2013). The construction of seamless supply chain network - development of "dry ports” in China. In R. Bergqvist, K. P. B. Cullinane, G. Wilmsmeier (Eds.), Dry ports: a global perspective. London: Ashgate.

McCalla, R. J. (1999). Global change, local pain: intermodal seaport terminals and their service areas. Journal of Transport Geography, 7(4), 247-254.

MOR (Ministry of Railways). (2008). Mid-to-long-term railway network plan. Beijing: MOR.

Monios, J. (2011). The role of inland terminal development in the hinterland access strategies of Spanish ports. Research in Transportation Economics, 33(1), 59-66.

Monios, J., \& Lambert, B. (2013). Intermodal freight corridor development in the United States. In R. Bergqvist, K. P. B. Cullinane, G. Wilmsmeier (Eds.), Dry ports: a global perspective. London: Ashgate.

Monios, J., \& Wilmsmeier, G. (2012). Giving a direction to port regionalisation. Transportation Research Part A: Policy \& Practice, 46(10), 1551-1561.

Nathan Associates. (2011). Corridor Diagnostic Study of the Northern and Central Corridors of East Africa. Action Plan. Volume One: main report. Arusha, Tanzania: East African Community.

Ng, A. K. Y., \& Cetin, I. B. (2012). Locational characteristics of dry ports in developing economies: some lessons from Northern India. Regional Studies, 46(6), 757-773.

Ng, K. Y. A., \& Gujar, G. C. (2009a). The spatial characteristics of inland transport hubs: evidences from Southern India. Journal of Transport Geography, 17(5), 346-356.

Ng, A. K. Y., \& Gujar, G. C. (2009b). Government policies, efficiency and competitiveness: the case of dry ports in India. Transport Policy, 16(5), 232-239.

Notteboom, T. (2008). Bundling of freight flows and hinterland network developments. In R. Konings, H. Priemus, \& P. Nijkamp (Eds.), The Future of Intermodal Freight Transport (pp. 6688). Cheltenham: Edward Elgar.

Notteboom, T. E., \& Rodrigue, J. (2005). Port regionalization: towards a new phase in port development. Maritime Policy \& Management, 32(3), 297-313. 
Notteboom, T., \& Rodrigue, J-P. (2009a). Inland terminals within North American \& European Supply Chains. In Transport and Communications Bulletin for Asia and the Pacific No. 78: Development of Dry Ports (pp. 1-39). New York: UNESCAP.

Notteboom, T., \& Rodrigue, J-P. (2009b). The future of containerization: perspectives from maritime and inland freight distribution. GeoJournal, 74(1), 7-22.

Olivier, D., \& Slack, B. (2006). Rethinking the port. Environment \& Planning A, 38(8), 1409-1427.

Parola, F., \& Sciomachen, A. (2009). Modal split evaluation of a maritime container terminal. Maritime Economics \& Logistics, 11(1), 77-97.

Pittman, R. (2004). Chinese railway reform and competition: lessons from the experience in other countries. Journal of Transport Economics \& Policy, 38(2), 309-332.

Pittman, R. (2011). Risk-averse restructuring of freight railways in China. Utilities Policy, 19(3), 152160.

Rimmer, P. J., \& Comtois, C. (2009). China’s container-related dynamics, 1990-2005. GeoJournal, 74(1), 35-50.

Robinson, R. (2002). Ports as elements in value-driven chain systems: the new paradigm. Maritime Policy \& Management, 29(3), 241-255.

Rodrigue J.P., Debrie J., Fremont A., \& Gouvernal E. (2010). Functions and actors of inland ports: European and North American dynamics. Journal of Transport Geography, 18(4), 519-529.

Rodrigue, J-P., \& Notteboom, T. (2009). The terminalisation of supply chains: reassessing the role of terminals in port/hinterland logistical relationships. Maritime Policy \& Management, 36(2), 165183.

Rodrigue, J-P., \& Notteboom, T. (2010). Comparative North American and European gateway logistics: the regionalism of freight distribution. Journal of Transport Geography, 18(4), 497-507.

Rodrigue, J-P., \& Notteboom, T. (2011). Looking inside the box: evidence from the containerization of commodities and the cold chain. Paper presented at the European Conference on Shipping and Ports, Chios Greece, June 2011.

Rong, Z., \& Bouf, D. (2005). How can competition be introduced into Chinese railways? Transport Policy, 12(4), 345-352. 
Roso, V., Woxenius, J., \& Lumsden, K. (2009). The dry port concept: connecting container seaports with the hinterland. Journal of Transport Geography, 17(5), 338-345.

Shi, L-P. (2009). Analysis on the Strategies of Tianjin's Waterless Port Construction. Logistics SciTech, 32(10) 19-21.

Slack, B. (2007). The terminalisation of seaports. In J. Wang, D. Olivier, T. Notteboom, \& B. Slack (Eds.), Ports, Cities and Global Supply Chains (pp. 41-50). Aldershot: Ashgate.

Slack, B., \& Wang, J. J. (2002). The challenge of peripheral ports: an Asian perspective. GeoJournal, 56(2), 159-166.

Theofanis, S., \& Boile, M. (2009). Empty marine container logistics: facts, issues and management strategies. GeoJournal, 74(1), 51-65.

van Klink, H. A., \& van den Berg, G. C. (1998). Gateways \& Intermodalism. Journal of Transport Geography, 6(1), 1-9.

Veenstra, A., Zuidwijk, R., \& van Asperen, E. (2012). The extended gate concept for container terminals: Expanding the notion of dry ports. Maritime Economics \& Logistics, 14(1), 14-32.

Wang, J. J., Rong, C., Xu, J., \& Or, S. W. O. (2012). The funding of hierarchical railway development in China. Research in Transportation Economics, 35(1), 26-33.

Wilmsmeier, G., Monios, J., \& Lambert, B. (2011). The directional development of intermodal freight corridors in relation to inland terminals. Journal of Transport Geography, 19(6), 1379-1386.

World Bank. (2009). Tracks from the Past, Transport for the Future: China's Railway Industry 19902008 and Its Future Plans and Possibilities. Beijing: Transport Coordinator, China Country Office.

Wu, J. H., \& Nash, C. (2000). Railway reform in China. Transport Reviews, 29(1), 25-48.

Xie, R., Chen, H., \& Nash, C. (2002). Migration of railway freight transport from command economy to market economy: the case of China. Transport Reviews, 22(2), 159-177. 